\title{
Die Semeia [tekens] in die Evangelie volgens Johannes
}

\begin{abstract}
Author:
Udo Schnelle $\mathrm{e}^{1,2}$

Affiliations:

${ }^{1}$ Martin-Luther University

Halle, Wittenberg Germany

${ }^{2}$ Faculty of Theology,

North-West University,

South Africa

Correspondence to:

Udo Schnelle

Email:

profschnelle@aol.com

Postal address:

Universität Halle,

Theologische Fakultät,

D-06099 Halle, Germany

\section{Dates:}

Received: 18 June 2014

Accepted: 04 Sept. 2014

Published: 30 Mar. 2015

How to cite this article:

Schnelle, U., 2015, 'Die

Semeia [tekens] in die

Evangelie volgens Johannes,

In die Skriflig 49(1), Art.

\#1849, 6 pages. http://dx.doi.

org/10.4102/ids.v49i1.1849

\section{Copyright:}

(C) 2015. The Authors.

Licensee: AOSIS

OpenJournals. This work is

licensed under the Creative

Commons Attribution

License.
\end{abstract}

Read online:

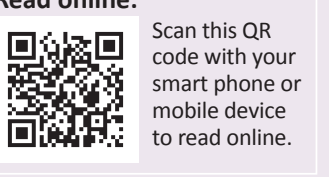

Die semeia in die Evangelie van Johannes word eerstens geanaliseer in verhouding tot soortgelyke wonderverhale, veral in die sinoptiese evangelies en ten tweede in verhouding tot die breër Johannese narratief. Duidelike ooreenkomste met sommige van die sinoptiese wonderverhale word bespreek. Dit lei tot die bevraagtekening van die sogenaamde 'semeiabron'-teorie. Opvolgend op hierdie diskussie word Johannes se eie interpretasie van die wonders nagegaan. Daar word veral aan die vervlegting van die wonderverhale met die teologie van Johannes aandag gegee, veral ten opsigte van die verhouding tussen die Vader en die Seun, geloof, die menslikheid van Jesus en die lyding van Jesus.

The Semeia in the Gospel according to John. The semeia in the Gospel of John are analysed, first in relation to other similar miracle narratives, especially in the synoptic gospels, and secondly in perspective of the broader narrative of John's Gospel. Clear links with some of the synoptic miracle narratives are discussed, questioning the 'semeia source' theory. This discussion is followed by a consideration of John's own interpretation of the miracles, exploring the interwovenness of the miracle stories with the theology of John, especially regarding the relation between the Father and the Son, the humanness of Jesus, the passion of Jesus and faith.

\section{Inleiding}

Die Johannese semeia [wondertekens] is van deurslaggewende belang vir die interpretasie van die Johannese Christologie, want volgens Johannes 10:41 is wonderwerke 'n onderskeidende kenmerk van Jesus as Messias. Die semeia is verder ook uiters belangrik vir die verstaan van die evangelie in die geheel, want om wondertekens ( $\sigma \eta \mu \varepsilon i \tilde{\alpha})$ te doen, vorm die begin (2:11), die draaipunt (12:37) en die einde (20:30) van Jesus se aktiwiteite in die Evangelie van Johannes. Johannes dui vir sy lesers aan hoe om die tekens te verstaan:

Jesus het nog baie ander wondertekens, wat nie in hierdie boek beskrywe is nie, voor sy dissipels gedoen. Maar hierdie wondertekens is beskrywe sodat julle kan glo dat Jesus die Christus is, die Seun van God, en sodat julle deur te glo, in sy Naam die lewe kan hê. (Joh 20:30-31) ${ }^{1}$

Dit dui aan wat Johannes se doel met die skryf van die Evangelie was, naamlik om geloof in die Seun van God aan te wakker en te hernu. Hierdie sterk teologiese stelling word ook binne die ná-Pase situasie met die Johannese konsep van die Parakleet verbind. Die Parakleet, die Heilige Gees en die Gees van die waarheid, leer en herinner die kerk aan wat Jesus gesê het (Joh 14:26) en funksioneer dus as die kerk se geheue. Die teenwoordigheid van die Parakleet maak dit moontlik om 'n meer diepgaande begrip van die inkarnasie, openbare bediening, lyding, verhoging en verheerliking van Jesus Christus te verkry (vgl. 14:15-17, 26; 15:26; 16:7-11, 13-15). ${ }^{2}$ Die spesiale perspektief van geloof in die ná-Pase anamnese onder leiding van die Parakleet lei Johannes om oor die betekenis van die goddelike inkarnasie te reflekteer. Daar moet vanuit Johannes se perspektief op geloof na die semeia in die Evangelie van Johannes gekyk word.

\section{Semeia [tekens] in die Evangelie van Johannes en die wondertradisies}

- Die wonderwerk te Kana is eie Johannese materiaal wat deur'n spaarsamige narratiewe styl en 'n totale konsentrasie op die werklikheid van die wonder en die krag van die Wonderwerker gekenmerk word. Vormkrities gesien is dit 'n 'gawe-wonderwerk' - Walter Bauer (1933:46)

1.Vir'n analise van die Johannese wonderwerktradisie, vergelyk Nicol (1972), Heekerens (1984), Schnelle (1992), Bittner (1987), Welck (1994) en Labahn (1999). Vir 'n oorsig oor die geskiedenis van navorsing, vergelyk Van Belle (1994).

2.Oor die linguïstiese aspekte van die woord $\pi \alpha \rho \alpha \kappa \lambda \eta$ tos, vergelyk Behm (1954:799-801). Relevante pogings om die standpunte uit die godsdiensgeskiedenis af te lei (Gnostisisme, Voorloper-Vervuller-idee, Advokaat-idee, Qumran, Afskeidsdiskoers-genre) is deur Burge (1987:10-30) byeengebring. Oor die godsdiens-historiese agtergrond van die Parakleetkonsep, vergelyk Müller (1975:31-77); parallelle kom ook voor in Schnelle (2001:689-693). 
noem dit 'n 'Luxuswunder' - in die klassieke styl (v. 1-2, uiteensetting; v. 3-5, voorbereiding vir die wonderwerk; v. 6-8, indirekte beskrywing van die wonderbaarlike gebeurtenis; v. 9-10, konkluderende bevestiging van die wonderwerk). Parallelle aan die 'gawe-wonderwerk'vorm kan in Lukas 5:1-11 en Johannes 6:1-15 e.v. gevind word. Die beelde wat die verteller kies, sluit aan by die wêreld van hellenistiese denke; alleen in daardie konteks word die motief van die verandering van water in wyn (Philostrat Vita Apollonii. 6, 10) gevind, en slegs daar word die titel $\alpha \rho \chi \imath \tau \rho i ́ \kappa \lambda ı v o \varsigma$ [hoofopsigter] gebruik. ${ }^{3}$

Die Kana-perikoop is van besondere belang vir sowel die Johannese konsep van wonderwerke as Johannes se teologie in die geheel. Johannes het Jesus se openbare bediening met ' $n$ wonderverhaal begin wat deur die hoogs gekondenseerde verhaalstyl en die wesenlike aard van die wonderwerk self die aandag uitsluitlik op die Een wat die wonderwerk doen, vestig. Die evangelis tel in Johannes 1:11 hierdie totale konsentrasie op die Wonderwerker op. Hy beskryf nie net die plek en die uitwerking van Jesus se eerste wonderwerk nie, maar deur middel van die doxa-konsep bring hy die wonderwerk, die vleeswording en die verheerliking in verhouding met mekaar en beklemtoon die sentrale rol van Jesus se wonderwerke. Die wonderwerke openbaar naamlik die preëksistensiële en verhewe Een en dit roep geloof op.

- Die genesing van die seun van 'n $\beta \alpha \sigma i \lambda$ ikòs [koning se amptenaar] in Johannes 4:46-54 berus op 'n gemeenskaplike tradisie met Matteus 8:5-13 en Lukas 7:1-10 (Wegner 1985). Selfs al kan geen literêre afhanklikheid gedemonstreer word nie, is die algemene kenmerke van die tradisie onmiskenbaar. Vanuit 'n godsdiens-historiese hoek vertoon Johannes 4:46-54 'n noue parallel met $b$. Berakot. 34b, wat rapporteer dat Rabbi Chanina, Ben Dosa 'n seun van Gamaliël II, deur gebed genees het. Albei gevalle vertel van genesing op 'n afstand waarin die motief van die uur 'n sentrale rol speel. Genesing op ' $n$ afstand kom in sowel Joodse as heidense kontekste voor. Die motief van wonderbaarlike voorkennis in Johannes 4:50 het indrukwekkende parallelle in die verhale oor Apollonius van Tyana. ${ }^{4}$

- 'n Johannese tradisie met sinoptiese trekke word ook in Johannes 5:1-9ab gevind. Die strukturele ooreenkomste met die sinoptiese semeia is onmiskenbaar (vgl. Mark 2:112; 3:1-6; Luk 7:11-1 7; 13:10-17). ${ }^{5}$ Daar is selfs 'n paar letterlike ooreenkomste (vgl. Joh 5:8 met Mark 2:11). Die motief van die helende krag van water kom in Joodse (Nicol 1972:56) en heidense kontekste voor en virì่s $\gamma \varepsilon v \varepsilon ́ \sigma \theta \alpha 1$ [om genees te word] in Johannes 5:6 en 9a kan moontlik 'n verwysing na die Asklepios-kultus ${ }^{6}$ bevat. Daar is 'n noue parallel met die demonstrasie van die

3.Parallelle in Schnelle (2001:107-110, 115 e.v.).

4.Vergelyk Philostratus Vita Apollonii. 1.32, 34; 4.18; 5.37; 7.10.

5.Vergelyk die tabel in Dodd (1963:175).

6. Hier kan 'n mens primêr aan die Asklepiosheiligdomme dink. Vir parallelle, vergelyk Rengstorf (1963:16-17) en Schnelle (2001:272-284). genesing (Joh 5:9ab) in Lucian se Philopseudes 11 (vgl. ook Philostrat Vita Apollonii. 4.45).

- Die wonderbaarlike voeding van vyfduisend en Jesus wat daarna volgens Johannes 6:1-25 op die water loop, is literêr en tradisie-histories van Markus 6:32-52 afhanklik. Kenmerkend van die voedingsverhaal is die intensifering van die wonderbaarlike in Johannes 6:7 en 11 en die eucharistiese eggo in vers 11 . Die naaste godsdienshistoriese parallel kom in 2 Konings 4:42-44 voor.

- Kenmerkend van Johannes 6:16-25 is die indrukwekkende beskrywing van ' $n$ wonderwerk. Hierdie narratief, wat oorspronklik 'n epifanie was, kombineer motiewe van op die see te loop en van die stilmaak van die storm met 'n verdere wonderwerk, naamlik die skielike aankoms van die boot aan die oewer in vers $21 \mathrm{~b}$. Godsdiens-historiese parallelle van loop op die see kom sowel in die $\mathrm{Ou}$ Testament as in hellenistiese bronne voor; dit blyk egter dat die motief van 'n boot wat wonderbaarlik vinnig by die land aankom in die pre-Christelike tye slegs in Griekse literatuur aangetref word (vgl. Schnelle 2001:345-350; 2008:310-319 vir parallelle).

- Die genesing van die blindgebore man in Johannes 9 is ook'n besondere tradisie van die Johannese skool. Hierdie semeion in 9:1-7 het sinoptiese (Mark 8:22-26; 10:46-52) en hellenistiese parallelle (vgl. Rein 1995). Die opmerking in vers 1 moet as ' $n$ beklemtoning van die buitengewone aard van die wonder beskou word: die bedelaar sou blind gebore wees. Die motief van blindheid as gevolg van sonde (v. 2) kom veral in Joodse bronne voor, maar ook in hellenistiese wonderverhale, hoewel in 'n ander vorm, naamlik van verblinding as straf (vgl. Schnelle 2001:480-488 vir parallelle). Verder is die helende krag van speeksel in die antieke geneeskunde bekend.

- 'n Verdere eie Johannese tradisie wat in 'n sterk geredigeerde vorm voorkom, is die opwekking van Lasarus in Johannes 11. In sy huidige vorm blyk die narratief inhoudelik swaar oorlaai te wees, maar in sy tradisionele, basiese vorm is dit, ten opsigte van die karakters (Luk 10:38-42; 16:19-31) asook die onderwerp (Mark 5:22-24, 35-43) baie naby aan die weergawes van soortgelyke sinoptiese tradisies en veral ook van Handelinge 9:36-42.

Die opwekking van Lasarus is die hoogtepunt van Jesus se openbare bediening en terselfdertyd aanleiding vir die finale besluit van die Joodse leiers om Jesus dood te maak (Joh 11:53). ${ }^{7}$ Johannes plaas opsetlik die grootste semeion op hierdie punt in sy narratief. Vir Jesus lei hierdie gebeurtenis die definitiewe pad na die kruis in; die hoorders of lesers van die Evangelie weet ook: Jesus wek Lasarus uit die dood op - God sal Jesus ook uit die dood opwek. So funksioneer die Lasarusverhaal terselfdertyd ook as 'n voorspel vir die verhaal van Jesus se eie lotsbestemming. Op 'n tweeledige wyse bied Johannes die einde van die verhaal oor die opwekking van Lasarus aan as 'n prototipe van die opstanding van Jesus. In die geval van Lasarus is 
die laaste rusplek, soos in die geval van Jesus, uit 'n rots gekap (vgl. Joh 11:38; 20:1); In albei gevalle is hulle ook volgens Joodse gebruike begrawe met albei se koppe wat in 'n doek toegedraai is (Joh 11:44; 19:40).

Aan die ander kant verraai kleiner gegewens die groot verskille tussen Lasarus en Jesus. In die geval van Lasarus is die graf steeds gesluit (11:38) terwyl die klip reeds weggerol is by Jesus (20:1). Waar Lasarus van die stukke lap bevry moet word (11:43-44), bevry Jesus Homself van sy grafkleed (20:6-7), soos gesien kan word uit die netjies opgevoude lap wat om Jesus se kop gedraai was. Ten slotte dui die gebruik van die frase ôv

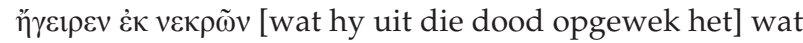
drie maal ten opsigte van Lasarus herhaal word (12:1, 9,

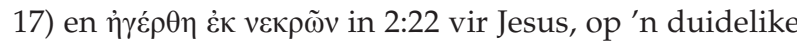
verband tussen die opwekking van Lasarus en die

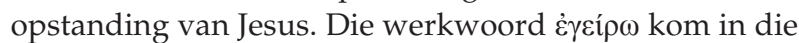
sin van 'uit die dood opgewek' slegs op hierdie plekke in die Evangelie voor (en ook in die epiloog in 21:14).

Samevattend kan gesê word dat die Johannes-evangelis, blykbaar wonderverhale uit die verskillendelyne van tradisies wat beskikbaar was, benut. Buiten verhale wat duidelik die eie tradisies in die Johannese groep verteenwoordig, is daar ook verhale wat met die sinoptiese verhale ooreenstem een vertelling waarvan die tradisiegeskiedenis nóú met die sinoptiese tradisie verbind is, asook twee wonderverhale uit die Markusevangelie.

Die godsdiens-historiese bevindings is kompleks. Nie net die Ou Testament en die Joodse motiewe en invloede nie, maar ook die hellenistiese en heidense motiewe en invloede kan gedemonstreer word. Hierdie resultaat staan teenoor alle pogings om die pre-Johannese wonderwerktradisie binne die raamwerk van slegs maar 'n semeia-bron ${ }^{8}$ te plaas as deel van 'n geslote tradisionele en godsdienstige agtergrond. In plaas daarvan toon die volgende beskrywing van die teologiese motiewe wat Johannes in sy hersiening van die wondertradisies gerig het, dat die evangelis doelbewus die individuele semeia na sy oortuigings geïnterpreteer het en op meer as een manier met die ander gedeeltes uit die evangelie verbind.

\section{Die Johannese interpretasie van Jesus se wonderwerke}

Uit Johannes 20:31 is dit duidelik dat die wonderwerke 'n teologiese funksie vir Johannes het: ' ... hierdie wondertekens is beskrywe sodat julle kan glo dat Jesus die Christus is, die Seun van God, en sodat julle deur te glo, in sy Naam die lewe kan hê.' Die evangelis relativeer nie die wonderwerke nie, maar integreer dit in sy teologiese opvatting. Ses motiewe is hier van belang.

\section{Wonderwerke en die openbaring van die doxa}

Vir Johannes het Jesus se wonderwerke openbaringskarakter. Die doxa [heerlikheid] van die Seun is deur die Vader 8.Vir'n kritiese bespreking van Fortna (1970), vergelyk Schnelle (1992:150-164). voor die grondlegging van die wêreld aan Hom gegee (Joh 17:5bc; 24cd; 12:41). Dit word in die menswording van die preëksistensiële Een geopenbaar (1:14ab), in sy wonderwerke gemanifesteer $(2: 11 ; 11: 4,40)$ en aan die kruis vervolmaak $(17: 1 b, 5,10 b, 22,24 c)$. Jesus se doxa is vroeg met die wynwonderwerk te Kana aan die lig gebring (2:11), en die laaste en grootste wonderwerk dien die enkele doel om die Seun te verheerlik (11:4) en so die doxa van die Vader te openbaar (11:40). Dit is verseker nie toevallig dat die evangelis die eerste en laaste wonderwerke in terme van die konsep van doxa interpreteer nie, aangesien dit Jesus se hele wonderwerkende bediening laat uitsien na die herhaalde openbaring van sy doxa. Die wonderwerke is inderdaad manifestasies van Jesus se doxa in die konteks van sy openbare bediening (vgl. Nicol 1972:119). Johannes gebruik doxa as instrument vir sy teologiese interpretasie van die oorgelewerde wondertradisies, asook as 'n verbinding van die semeia met sy teologie.

Daarbenewens gebruik Johannes die konsep, doxa, om Jesus se wonderwerke met die begin en die einde van sy hele bediening te verbind, naamlik, inkarnasie aook verheerliking. Die wonderwerke is nie maar net ' $n$ episode in die lewe en bediening van die geïnkarneerde Jesus nie en moet ook nie bloot simbolies verstaan word nie. ${ }^{9}$

\section{Wonderwerke en die eenheid van die Vader en die Seun}

Die wonderwerke getuig van die eenheid van die Seun met die Vader. Die Seun doen die werke van die Een wat Hom gestuur het en die wonderwerke is niks anders as $\tau \grave{\alpha}$ है p $\gamma \alpha$

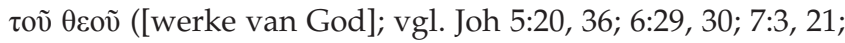
9:3b-5; 10:25, 32 e.v., 38; 14:10-11; 15:24) nie. Veral in 9:3b-5 verbind die evangelis Jesus se wonderwerk-aktiwiteit aan die totale verlossende gebeurtenis wat in 4:34 en 17:4 ع́p pov [werk] genoem word. Dit is juis as 'n uitdrukking van die innerlike vereniging wat tussen die Vader en die Seun bestaan dat die wonderwerke Jesus legitimeer. Die Een wat sulke dinge doen, kan net van God kom (vgl. 9:16, 30, 33; 11:42); God moet met Hom wees (3:2). Die werke wys na Jesus se oorsprong (sien $\pi$ ó $\theta \varepsilon v$ [vanwaar] in 9:30) en bevestig dat Hy deur die Vader gestuur is. Omdat 'die Vader en die Seun Een is' (10:30: '̇ү⿳亠े

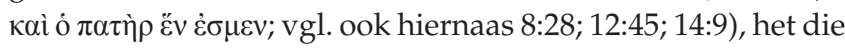
Vader aan die Seun mag oor die lewe gegee (10:28-30; 17:2). Jesus gebruik hierdie krag wanneer Hy die sterwende seun van die koninklike amptenaar genees (vgl. veral 4:47c, 49) en ook Lasarus uit die dood opwek (vgl. veral 11:20-27).

Deur die motief van die eenheid van die Vader en die Seun verenig die evangelis die semeia met die sentrum van sy Christologie: die beslissende en onoortreflike openbaring van die Vader wat in sy Seun verskyn.

\section{Wonderwerke en geloof}

Soos Jesus se hele bediening 'n openbaring en verheerliking van die Vader deur die Seun is, en die Seun deur die Vader (Joh 8:54; 12:28; 13:31-32; 14:13), so is die wonderwerke die

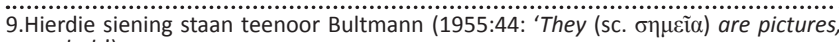
symbols'). 
spesifieke lokus van hierdie openbaring. Dit is nie net 'n verwysing na die doxa nie maar is self 'n uitdrukking van hierdie doxa (vgl. Schnelle 1991:164-167). Die openbaring van Jesus se doxa in die wonderwerke roep geloof op omdat geloof volgens Johannes direk aan Jesus se werke gekoppel is. In die verhaal van die bruilof in Kana brei die evangelis op sy begrip van wonderwerk en geloof uit en gebruik die dissipels as 'n voorbeeld (2:11: 'Jesus het hierdie eerste een van sy tekens te Kana in Galilea gedoen en sy heerlikheid geopenbaar, en sy dissipels het in Hom geglo'). Dit is nie die geval dat geloof eerste is en dat dit getuies na die geleentheid laat kyk as 'n wonderwerk nie, maar dat geloof deur die openbaring van Jesus se heerllikheid in die wonderwerk ontstaan. Omdat die wonderwerk 'n openbarende karakter het en kragtig van die eenheid van die Seun met die Vader getuig, is dit in staat om geloof op te wek. Die skare het ook later in Jesus geglo as gevolg van sy wonderwerke (2:23). Enigiemand wat sulke dade doen, kan net die ware profeet wees wat in die wêreld gekom het, of die Christus (6:14; 7:31; vgl. ook $6: 2 ; 9: 16 ; 12: 18)$. So kom die man wat blind gebore is ook deur middel van ' $n$ wonderwerk tot geloof in die Een wat sy oë geopen het (9:35-38).

In welke mate wonderwerke en geloof in Johannes saamhang, kan in Johannes10:40-42 gesien word met die essensiële verskil tussen Jesus en Johannes die Doper. Johannes het geen wonderwerke gedoen nie en daarom glo baie in Jesus, maar nie in Johannes nie. Verder maak 11:15 dit duidelik dat geloof deur wonderwerke ontstaan. Jesus is bly dat die dissipels nie teenwoordig was toe Lasarus gesterf het nie. Nou kan Hy sy vriend opwek sodat die dissipels kan glo (iv $\pi \iota \tau \tau \varepsilon v \sigma \eta \tau$ ). Die wonderwerke vind nie hier toevallig plaas nie. Dit word doelbewus gedoen met die oog op geloof. ${ }^{10}$ Verse 40 en 45 werp ook lig op die verband tussen wonderwerk en geloof in die Lasarusperikoop. Marta vertrou in Jesus se krag en sien

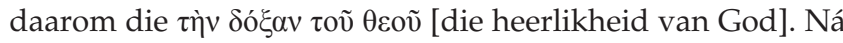
die wonderwerk glo baie Jode ook in Jesus (11:45, 48; 12:11).

Vir die evangelis, Johannes, lei wonderwerke tot geloof; vir

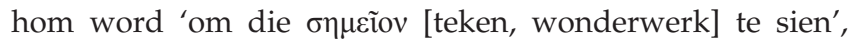
gevolg deur 'om in Jesus Christus te glo'.

Hierdie verband tussen om te sien en om te glo, word verder duidelik gemaak in Johannes 2:11, 23; 4:53; 6:14; 7:31; 9:3538 ; 10:40-42; 11:15, 40,45; 12:11; 20:8, 25, 27, 29a en speel 'n sentrale rol in die manier waarop die vierde evangelis geloof verstaan. Geloof ontstaan uit die wonderwerk wat reeds plaasgevind het; dit is nie geloof wat die wonderwerk moontlik maak nie. Johannes sien dus hoegenaamd nie geloof in wonderwerke as bloot ' $n$ 'voorlopige, eerste-vlak geloof' nie; die wonderwerk genereer nie net 'n verwysing na die geloof, of 'n tweedehandse of onvolledig geloof nie, ${ }^{11}$ maar geloof in die volle sin van die woord, naamlik om te erken dat Jesus Christus die Seun van God is en Hom as

10.Daar is nie fundamentele kritiek op wonderwerke in Johannes $2: 24-25 ; 4: 48 ; 6: 30$ $20: 29 \mathrm{~b}$ nie. Jesus verwerp slegs die eis of versoek vir'n wonderwerk (4:48;6:30), of andersins die twyfelagtige geloof van die skare (2:24-25; vgl. Bittner 1987:122-134).

11. Hierdie staan teenoor Bultmann (1955:73): 'Genuine faith must not be confused with a seeming faith that is aroused by Jesus' 'signs'...'. sodanig te aanvaar. Dit is dus nie 'n geval dat geloof slegs die dat van die openbarende gebeurtenis as inhoud het nie. ${ }^{12}$ Die wonderwerke beskryf eerder met 'n duidelikheid en realisme wat skaars oortref kan word, die werk van die Openbaarder in die geskiedenis. Om die wonderwerke te sien, is dus nie bloot 'n geestelike persepsie nie, maar is om iets te sien wat in die werklikheid sigbaar is. ${ }^{13}$

\section{Wonderwerke en ongeloof}

Jesus se wonderwerke roep geloof en ongeloof op. Die evangelies formuleer hierdie situasie in programmatiese modus in Johannes 12:37: 'Hoewel Hy so baie tekens in hulle teenwoordigheid verrig het, het hulle nie in Hom geglo nie.' Selfs Jesus se broers glo nie in Hom nie (7:5), alhoewel hulle sy werke (7:3) gesien het. Die genesing van die man wat blind gebore is, lei tot geloof én ongeloof onder die Jode (9:16).

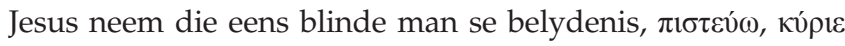
[Here, ek glo] in 9:38, as 'n geleentheid om die karakter van sy sending as 'n oordeel te beklemtoon. 'n Persoon se houding (geloof of ongeloof - vgl. 3:18) teenoor Jesus se wonderwerke is deurslaggewend vir die oordeel (9:39). Die opwekking van Lasarus lei baie Jode tot geloof (11:45) maar terselfdertyd verraai sommige Hom daardeur aan die Joodse leiers (11:46).

Johannes gebruik die wonderwerke om die aard van ongeloof te demonstreer, want in die lig van die $\sigma \eta \mu \varepsilon i \alpha$ is ongeloof die ontkenning van 'n onteenseglike werklikheid: Jesus Christus is die Seun van God. Die kentekens van ongeloof is nie ' $n$ gebrek aan kennis of 'n onvermoë om te glo nie, maar ongeloof is eerder die doelbewuste ontkenning van 'n onmiskenbare en openbaar-sigbare feit.

Die verband tussen wonderwerke en ongeloof dui ook daarop dat die wonderwerke nie vir die evangelis magies werk nie. Ten spyte van hulle openbarende karakter, belangrikheid en werklikheid vereis wonderwerke 'n besluit van die kant van menslike getuies. Tot die mate wat Jesus se wonderwerke die geleentheid vir sowel geloof as ongeloof kan wees, vorm dit 'n sentrale element in Jesus se hele bediening, en die resultaat is dat sommige mense glo en ander nie (vgl. 5:47; 6:36, 64; $8: 45,46 ; 10: 25,26 ; 16: 9)$.

\section{Wonderwerke en Jesus as mens}

Die realiteit van die wonderwerke word gedemonstreer deur hulle merkwaardige afmetings en deur die feit dat hulle geverifieer kan word (Joh 2:9-10; 4:51 e.v.; 5:2, 5; 6:13; 9:9, $20,25,39 ; 11: 18,39,44)$ as die goddelike teenwoordigheid in die wêreld. Terselfdertyd beklemtoon die semeia asook ander sentrale narratiewe gegewens die menslikheid van Jesus (vgl. hieroor Thompson 1993:53-86). Hy woon 'n huweliksbevestiging by (2:1-11), het sy vriend Lasarus lief (11:3), is diep getref deur die hartseer van ander (11:33-34)

12. In die klassieke tesis van Bultmann (1955:66) staan: 'John, that is, in his Gospel presents only the fact (das Dass) of the Revelation without describing its content (ihr Was)'.

13. Bultmann (1976:66) dui die sigbaarheid van die Openbaarder hierteenoor aan as ' $n$ 'pietistic misunderstanding', en meen dan: 'Accordingly in the Johannine portrayal of the incarnate Revealer there is no attempt to present him as a visible figure; to of the incarnate Revealer there is no attempt to present him as a visible figure; to
encounter the Revealer is not to be presented with a persuasive set of answers but only to be faced with a question. 
en huil by die graf van Lasarus (11:35). Jesus kom uit Nasaret in Galilea $(1: 45-46 ; 4: 44 ; 7: 41,52)$, en nie uit Bethlehem nie $(7: 41,42)$, sy ouers is bekend $(1: 45 ; 2: 1,3,12 ; 6: 42 ; 19: 26)$ en so ook sy broers (2:12; 7:1-10). Hy het 'n sterflike liggaam (2:21) van vlees (6:51) en bloed (19:34). Hy reinig die tempel met groot lyding (2:14-22) en sy reis te voet maak Hom moeg en dors (4:6-7). In die lig van die bestemming voor Hom (12:27; vgl. 13:21) beleef Jesus innerlike onrus of opgewondenheid en aan die kruis vra Hy vir iets om te drink (19:28). Pilatus laat sy soldate toe om Hom met die sweep en dorings te martel (19:1-2) en verklaar dan ewe amptelik: 'Kyk, hier is

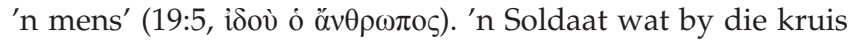
diens doen, maak dit duidelik dat Jesus in werklikheid dood is (19:38). By sy begrafnis word sy liggaam met speserye voorberei om die verwagte stank van 'n lyk teen te werk (19:39-40). Die dissipels (en uiteindelik ook Tomas kan bevestig dat hulle die liggaam van die opgestane Jesus met hulle eie oë gesien het en dat dit identies is met dié van die aardse en gekruisigde Jesus (20:20, 27).

Die teologiese punt is duidelik: deur sy reddende handelings in die wêreld het God Homself onlosmaaklik aan die mens, Jesus van Nasaret, en sy werk verbind. God self praat en tree in Jesus op en dit in 'n eksklusiewe en onoortreflike sin. God se woord kan nêrens anders gehoor word nie (5:39-40) en God se werke kan ook nêrens anders as deur die mens, Jesus van Nasaret, ervaar word nie $(3: 35 ; 5: 20-22)$.

\section{Wonderwerke en die lyding van Jesus}

Die Joodse leiers se ongeloof lei tot Jesus se kruisiging. Hulle finale besluit om Jesus dood te maak, volg op sy kragtigste daad, die opwekking van Lasarus (Joh 11:53). Dit illustreer duidelik die onafhanklikheid van die vierde evangelis om sy werk saam te stel. Hy het die reiniging van die Tempel (vgl. Schnelle 1996:259-373), wat vir die sinoptici die uiteindelike rede vir die besluit was om Jesus dood te maak (vgl. Mark 11:17; Luk 19:47), aan die begin van sy Evangelie geplaas (Joh 2:14-22). Hierdeur beklemtoon hy die onderlinge verband tussen die wonderverhale en die theologia crucis. Hierdie noue verband tussen wonderwerke en die lyding (vgl. Joh 11 , veral verse $8-10,16$ ) word ook deur die verwysings na die lyding in die ander semeia versterk.

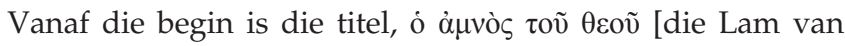
God], op die lippe van Johannes die Doper $(1: 29,36)$ en dit verwys na die lyding soos dit duidelik word in 2:1-11. Met

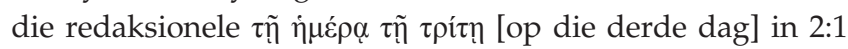
verwys Johannes na die oggend van die opstanding, en ov̋ $\pi \omega$

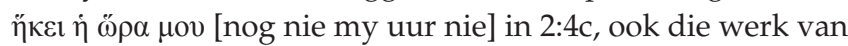
die evangelis, dui op die uur van die lyding. Reeds in die eerste wonderwerk is daar' $n$ aanduiding van wat in die laaste uur sal gebeur: Jesus se bediening van wonderwerke sal tot lyding aanleiding gee. Op die plek waar die Seun van God sy doxa openbaar, ontvlam en woed tegelykertyd ongeloof.

Die evangelis verbind met Johannes 2:13 die eerste deel van die dubbele tradisie tot sy beskikking (2:1-10, 12; 4:46b, 47, 50-53; vgl Schnelle 2009a:68-74, 108-113); die reiniging van die tempel met sy posisionering aan die begin van die Evangelie, plaas Jesus se aktiwiteit van die begin af in die skaduwee van die kruis. Johannes 2:17, 20-22 gee 'n aanduiding van die evangelis se ná-Pase perspektief. Hy interpreteer die verhaal van Jesus op die basis van die kruis en opstanding. Die betekenis van Jesus se bediening asook van die Skrifgetuienis word slegs deur die kruis en opstanding geopenbaar, want dit is in die oorgawe van sy eie liggaam dat Jesus sy reddende werk voltooi.

Die herhaalde beskrywings van die reise na die godsdienstige feeste, asook ander verwysings na die feeste (2:23;5:1; 6:4;7:2, 10; 11:18, 55 e.v.) het ook die uitsluitlike doel om Jesus herhaaldelik na Jerusalem te bring of om sy aktiwiteit aan Jerusalem te verbind, waar sy lot ook vervul sal word. Baie Jode het in Jesus begin glo deur die wonderwerke wat Hy gedurende die Paasfees in Jerusalem gedoen het. Die genesing by die poel van Siloam (Joh 9) gebeur tydens 'n fees in Jerusalem. Die voeding van vyfduisend en Jesus wat op die see loop, vind plaas - en vanuit die evangelis se oogpunt is dit nie toevallig nie - tydens die Pasga, in die teenwoordigheid van 'n groot skare. Jesus se broers moedig Hom aan om na die Loofhuttefees te gaan sodat Hy wonderwerke voor die skare daar kan doen. Maar Jesus gaan in die geheim na die fees omdat Hy weet dat die Jode Hom wil doodmaak. Johannes intensifeer doelbewus die genesing van die verlamde man by die poel en die genesing van die man wat blind gebore is op die Sabbat (5:9c; 9:14). Daarmee verskerp die konflik tussen Jesus en die Jode en word die wonderwerke as oorsaak vir die vervolging van Jesus en sy volgelinge geteken $(5: 16 ; 9: 4,16,22,34)$.

Vir Johannes is die wonderwerke komposisioneel en in terme van hulle inhoud ' $n$ uitdrukking van sy theologia crucis. ${ }^{14}$

\section{Gevolgtrekkings}

Sowel die sinoptici as die Evangelie van Johannes plaas die sentrale fokus van hulle verhale op Jesus se invloedryke bediening as bedienaar van wonderwerke en wondergeneser. Albei is dit op hierdie punt histories eens: Jesus was 'n Wonderwerker. Maar Johannes stel nie belang in die vraag na die historisiteit van die individuele wonderwerke nie. Hy aanvaar die historiese feit van Jesus se wonderwerke en integreer dit in sy teologiese opvatting, naamlik dat wonderwerke gebeure is waardeur die genadige God Homself na die wêreld draai.

Jesus draai na mense veral in sy wonderwerke; die konsep van waarneembare tekens is 'n sentrale element van die vierde Evangelie se inkarnasie-Christologie. Johannes integreer sewe semeia in sy Evangelie, 'n uitdrukking van die getal sewe wat verteenwoordigend is van volheid en voltooiing soos dit ook uit Genesis 2:2 blyk. Elke tipe wonderwerk kom net een keer in Johannes voor. Die individuele semeia word stelselmatig regdeur die openbare bediening van Jesus versprei. Dit illustreer 'n sentrale aspek van Johannes se Christologie, naamlik die reddende goddelike teenwoordigheid in

14.Vir die Johannese theologia crucis, vergelyk Schnelle (2009b:694-703). 
die mensgeworde Een, wat as die bemiddelaar van die skepping lewe aan die begin geskep het (Joh 1:3), is self die lewe (1:4) asook die Gewer van die lewe aan ander. Hierdie kreatiewe, lewegewende krag word in die volheid van die wonderwerke geopenbaar. Johannes verdiep die sinoptiese weergawes daarvan tot die uitnemende. Jesus verander nie bloot die water in wyn nie, maar vul ses groot houers met bykans 700 liter wyn (2:111). Die afstandsgenesing van die seun van 'n koninklike amptenaar vind nie in dieselfde dorp plaas nie - Jesus genees die seun in Kapernaum terwyl Hy in Kana is (4:46-54). Die lam man by die poel van Bethesda is reeds vir 38 jaar siek (5:1-9). By die wonderbaarlike voeding van die vyfduisend kon almal soveel eet as wat hulle wou en ten spyte daarvan het daar nog twaalf groot mandjies vol brood oorgebly (6:1-15). Jesus het nie net op die see geloop en ook die dissipels uit hulle moeilikheid gered nie (6:16-20) maar Hy doen die bykomende wonderwerk deur die boot vinnig by sy bestemming te bring (6:21). Jesus genees ook die oë van 'n man wat van sy geboorte af blind was (9:1-41). Lasarus was reeds vier dae dood en sy liggaam was op die punt van ontbinding toe Jesus hom uit die dood opgewek het; selfs al was sy hande en voete verbind en sy gesig deur ' $n$ doek bedek, het Lasarus op bevel van Jesus uit die graf gestap (11:1-44).

As kragtige dade deur 'die Woord wat vlees geword het', het die wonderwerke in die Evangelie van Johannes 'n fundamentele funksie. Met hulle digtheid en realisme wys dit dat Jesus Christus werklik ruimte en tyd binnegekom het. Die gelyktydige klem op Jesus se menslikheid is bedoel om die vleeslike bestaan van die Wonderwerker aan te toon. Wanneer geloof volg wanneer mense die wonderwerke sien, beteken dit dat Johannes op die belang van geloof in Jesus se verskyning in die vlees aandring. Die wonderwerke is demonstrasies van Jesus se heerlikheid in die wêreld en maak terselfdertyd deel van die Johannese theologia crucis uit. Dit maak die doxa van die vleesgeworde Een sigbaar en roep geloof op. Op hierdie wyse verbind en verseker die wonderwerke uitdruklik die identiteit van die preëksistensiële Een met die vleeslike, lydende en verhewe Jesus Christus.

In teenstelling met die onderwaardering van die Johannese semeia wat vandag by geleerdes voorrang geniet, moet beklemtoon word dat op grond van die voorafgaande ontledings, die wonderwerke van fundamentele belang vir die Christologie van die vierde evangelis is. Die openbaring van Jesus se doxa vind nie ná nie, maar ín die wonderwerk plaas. Die wonderwerke is nie bloot ' $n$ toegewing aan menslike swakheid nie; inteendeel, dit is demonstrasies van die 'heerlikheid van God'.

Die tekens vorm die narratiewe basis van die hele Evangelie: die wonderverhale lei die leser tot die besef dat Jesus sy oorsprong in God het, dat Hy God se Woord is, naamlik die Seun wat die Vader gestuur het en die Een wat die ewige lewe bring.

\section{Erkenning Mededingende belange}

Die outeur verklaar dat hy geen finansiële of persoonlike verbintenis het met enige party wat hom nadelig of voordelig kon beïnvloed het in die skryf van hierdie artikel nie.

\section{Literatuurverwysings}

Bauer, W., 1933, Das Johannesevangelium, 3rd ed., Mohr, Tübingen.

Behm, J., 1954, Art. П $\alpha \rho \alpha, \mathrm{k} \lambda$ птоৎ, Kohlhammer, Stuttgart.

Bittner, W.J., 1987, Jesu Zeichen im Johannesevangelium: Die Messias-Erkenntnis im Johannesevangelium vor ihrem jüdischen Hintergrund, Mohr, Tübingen. (Wissenschaftliche Untersuchungen zum Neuen Testament II).

Bultmann, R., 1955, Theology of the New Testament, vol. 2, transl. K. Grobel, SCM, London.

Bultmann, R., 1976, The Gospel of John, 3rd ed., transl. G.R. Beasly-Murray, Fortress, Philadelphia.

Burge, G.M., 1987, The anointed community, Eerdmans, Grand Rapids.

Dodd, C.H., 1963, Historical tradition in the fourth Gospel, Cambridge University Press, Cambridge.

Fortna, R.T., 1970, The gospel of signs, Cambridge University Press, Cambridge.

Frey, J., 2000, Die johanneische Eschatologie, T. 3, Mohr, Tübingen. (Wissenschaftliche Untersuchungen zum Neuen Testament 117).

Heekerens, H-P., 1984, Die Zeichen-Quelle der johanneischen Redaktion: Ein Beitrag zur Entstehungsgeschichte des vierten Evangeliums, Verlag Katholisches Bibelwerk, Stuttgart.

Labahn, M., 1999, Jesus als Lebensspender: Untersuchungen zu einer Geschichte der johanneischen Tradition anhand ihrer Wundergeschichten, De Gruyter, Berlin. (Beihefte zur Zeitschrift für die neutestamentliche Wissenschaft 98).

Müller, U.B., 1975, 'Die Parakletvorstellung im Johannesevangelium', Zeitschrift für TK 71, 31-77.

Nicol, W., 1972, The Semeia in the fourth Gospel: Tradition and redaction, Brill, Leiden. (Novum Testamentum Supplement 32).

Rein, M., 1995, Die Heilung des Blindgeborenen, Mohr, Tübingen. (Wissenschaftliche Untersuchungen zum Neuen Testament II 73).

Rengstorf, K.H., 1963, Christusglaube und Asklepiosfrömmigkeit, Schriften zur Förderung der Westfälischen Landesuniversität, Münster.

Schnelle, U., 1992, Antidocetic Christology in the Gospel of John, Fortress, Minneapolis.

Schnelle, U.,1996, 'Die Tempelreinigung und dieChristologie des Johannesevangeliums', NTS 42, 359-373. http://dx.doi.org/10.1017/S002868850002083X

Schnelle, U., 2001, Neuer Wettstein, 1, 2: Texte zum Johannesevangelium, De Gruyter, Berlin.

Schnelle, U., 2008, Neuer Wettstein 1, 1.1: Texte zum Markusevangelium, De Gruyter, Berlin.

Schnelle, U., 2009a, Das Evangelium nach Johannes, 4th ed., Evangelische Verlagsanstalt, Leipzig.

Schnelle, U., 2009b, Theology of the New Testament, transl. M.E. Boring, Baker Academic, Grand Rapids.

Sproston North, W.E., 2001, The Lazarus story within the Johannine tradition, Sheffield Academic, Sheffield. (Journal for the study of the New Testament, Supplement 212).

Thompson, M.M., 1993, The incarnate Word: Perspectives on Jesus in the fourth Gospel, Hendrickson, Peabody.

Van Belle, G., 1994, The signs source in the fourth Gospel: Historical survey and critical evaluation of the semeia hypothesis, Leuven University Press, Leuven.

Wegner, U., 1985, Der Hauptmann von Kapernaum, Mohr, Tübingen, (Wissenschaftliche Untersuchungen zum Neuen Testament II 14).

Welck, C., 1994, Erzählte Zeichen: Die Wundergeschichten des Johannesevangeliums literarisch Untersucht; mit einem Ausblick auf Joh 21, Mohr, Tübingen. (Wissenschaftliche Untersuchungen zum Neuen Testament II 69). 